=

DOI: $10.31857 / \mathrm{S} 032103910015603-6$

\title{
CHRONOLOGY OF THE "FAT BOY GROUP” SKYPHOI AND AMPHORAE FROM THE PRIKUBANSKIY BURIAL GROUND
}

\author{
Elena V. Kuznetsova ${ }^{1}$, Natalya Yu. Limberis ${ }^{2}$, \\ Ivan I. Marchenko ${ }^{3}$, Sergey Yu. Monakhov ${ }^{4}$ \\ ${ }^{1,4}$ Saratov State University, Saratov, Russia \\ ${ }^{2,3}$ Kuban State University, Krasnodar, Russia \\ ${ }^{1}$ E-mail: ev_kuznetsova@list.ru 2,3 E-mail:meot@mail.ru \\ ${ }^{4}$ E-mail: monachsj@mail.ru
}

The article discusses four graves of the Maeotian burial ground «Prikubanskiy» (№ 186, 253, 262,384 ), dating from $c a .400-350$ B.C. Their funeral equipment included, along with local hand-made and fired pottery, red-figure skyphoi of the «fluent» style (F. B. Group), amphorae of different production centers, and a few black-glazed vessels. Cross-dating of various categories of ceramic imports has narrowed the chronology of table vessels and ceramic containers.

Keywords: burial ground «Prikubanskiy», Maeotian culture, ceramic imports, amphorae, redfigured skyphoi, black-glazed pottery

Authors. Elena V. Kuznetsova - PhD (History), Curator of the collections of the Institute of Archaeology and Cultural Heritage of the Saratov State University; Natalya Yu. Limberis Senior Scientific Assistant of the Scientific Research Institute of Archaeology of the Kuban State University; Ivan I. Marchenko - PhD (History), Professor of the Faculty of History, Sociology and International Relations of the Kuban State University; Sergey Yu. Monakhov Dr. (Hab. History), Head of the Chair of the History of the Ancient World, Director of the Institute of Archaeology and Cultural Heritage of the Saratov State University.

This article is a translation of: Кузнецова Е. В., Лимберис Н. Ю., Марченко И. И., Монахов С.Ю. Хронология скифосов «беглого стиля» и амфор из Прикубанского некрополя. Journal of Ancient History [Vestnik drevney istorii] 81/1 (2021), 149-165. DOI: 10.31857/ S032103910013527-2.

The study was conducted with the financial support of the Russian Scientific Foundation (Project no. 18-18-00096). 
I

n 1998-2001, in the course of rescue investigations of the Krasnodar archaeological expedition of the Kuban State University, a considerable area of a Maeotian necropolis was excavated near the khutor (farmstead) of Prikubansky (Krasnoarmeysky district of Krasnodar Territory), that is situated in the flood-plain part of the right bank of the Kuban River, in its lower reaches. Totally, during these four years, 429 burials have been excavated where several thousand items of burial inventory including Maeotian wheelmade pottery and handmade ceramics, jewellery, weapon, etc. were found. Also a large quantity of imported ceramic ware was uncovered. A monographic publication of all the finds is expected in the nearest future, but in the present article, we wish to publish a small block of four complexes (burials nos. 186, 253, 262 and 384) which comprise a set of Attic red-figure skyphoi and amphorae from different production centres. Cross-dates of these categories of pottery considerably supplement our notions of import dynamics of Greek products to the Maeotian milieu. Analysis demonstrates that Attic red-figured skyphoi were brought to the Maeotians of the Kuban region during a brief period within the first half of the $4^{\text {th }}$ century B.C.

In the burials mentioned, four red-figure skyphoi of the Attic type (type A) with painting in a 'fluent' style have been uncovered. In its style, the painting of these vessels is comparable to the latest group of the Attic red-figure ware ('Fat Boy Group' or the F.B. Group after J.D. Beazley). Fragments with details of a painting of this type and a single archaeologically complete skyphos of this group from the Athenian Agora are dated to the second - third quarters of the $4^{\text {th }}$ century B.C. ${ }^{1}$ These skyphoi belong to the number of the vessels which were copiously distributed throughout the world of the Classic period until the mid- $4^{\text {th }}$ century B.C. ${ }^{2}$

All the skyphoi here considered are produced from light-brown clay without discernible admixtures suggesting their Attic origin. In terms of their shape they have walls sagged near the bottom and an outturned pointed rim. The handles are of round section and trapezoid in the plan, slightly raised. The foot is rounded with a raised edge. The red-figure painting in the 'fluent' style, rather carelessly applied, is similar on all these items in its subject and manner of representations: palmettes beneath the handles, and volutes at the sides of the handles. Between the handles, paired figures are represented of young men draped in himation standing opposite each other with muffled hands. The glaze covers the inner and near-bottom parts of the vessels as well as the handles. The glaze is black with brown spots.

Totally, at the Maeotian sites on the right bank of the Kuban, now there are known 24 red-figure skyphoi in the 'fluent' style (including the fragmentary and reused bottom parts). Only 9 items among them are archaeologically complete forms. A complete skyphos in an excellent state of preservation found in burial 46 of kurgan 2 at the Sereginskaya necropolis in the trans-Kuban region is dated to the second quarter of the $4^{\text {th }}$ century B.C. ${ }^{3}$ Generally, the period of the use of skyphoi with 'fluent' painting, as

\footnotetext{
${ }^{1}$ Moore 1997, 63, No. 1303-1305.

${ }^{2}$ Ivanov 1963, 199-201, Pl. 106-108, № 485-488; Trias de Arribas 1967, I, 272, 298, 399, 506-507, lám. CLXIV, 1, 7; CLXVI, 13; CLXXXI, 1; CLXXXV, 5; CCLVI; CCLVII; Picazo 1977, 73, lám. XX; Stoyanov, Erim-Ozdogan 2014, 174-175, Fig. 3, 8a-8b, Cat. № 25.

${ }^{3}$ Leskov, Lapushnian 1987, 149, Cat. № 206, Photo XXV; erroneously dated to the late $4^{\text {th }}$ century B.C.
} 
demonstrated by the complexes of the Prikubansky necropolis, is limited by the first early third quarter of the $4^{\text {th }}$ century B.C. ${ }^{4}$ This date corresponds well with the chronological situation with analogous ware in the Northern Black Sea littoral ${ }^{5}$ and on the Lower Don ${ }^{6}$.

For a more complete idea about the Maeotic complexes here considered, a brief description of the burials (in the chronological order) will be presented below while redfigure skyphoi, other black-glazed vessels and amphorae from different production centres encountered in association with them will be separately analysed.

\section{BURIAL NO. 253}

This burial was looted in antiquity, no human skeletal remains were here found ${ }^{7}$. The grave goods: red-figure skyphos, two Thasian amphorae, mesh lekythos, handmade and grey-ware pottery, a bronze mirror and several small objects (spindle-whorl, beads, knife).

Of four skyphoi, the vessel from burial No. 253 (Fig. 1, 2) is distinguished in its squatter shape (with slightly tapering lower body) and, according to the standards of the Athenian Agora, it is datable to a slightly earlier time than the ware from other burials, i.e. to a range within $400-375$ B.C. ${ }^{8}$, as already noted before ${ }^{9}$. As to the painting, on this vessel also the figures of two youths in himation facing each other are depicted. A similar in its style fragment of a skyphos from the Athenian Agora is dated to the beginning of the $4^{\text {th }}$ century B.C. ${ }^{10}$ Therefore the skyphos from burial No. 253 can be perhaps considered as belonging to a group preceding that of 'Fat Boy' (F.B. Group).

The same burial yielded a lekythos with mash ornament (Fig. 1, 1) of which only the upper body is preserved; however it is obvious that this toilet vessel belongs to the Boulas Group $^{11}$. The beginning of the manufacture of such lekythoi in the Mediterranean region is dated to the first quarter of the $4^{\text {th }}$ century B.C., while their mass production and wide use in the funerary rite falls on the second - third quarters of that century ${ }^{12}$. This date coincides with the period of the regular burying of such lekythoi at necropoleses of the Northern Black Sea Region ${ }^{13}$. Mash lekythoi are fairly rare finds at Maeotian burial grounds. Thus three complete examples were found in the Maryanskaya (Maryinskaya) kurgan ${ }^{14}$, and yet another one was retrieved from the ritual complex of the Tenginskaya necropolis in the Transkuban region ${ }^{15}$. Several fragmentary examples come from the cemetery of

${ }^{4}$ Limberis, Marchenko 2015, 234-239.

${ }^{5}$ Rogov, Tunkina 1998, 165; Maslennikov 2012, 70, 72, № 12, 13, Fig. 2, 4-5a; Vdovichenko et al. 2019, 49, № 290-326.

${ }^{6}$ Brashinskiy 1980, 55.

${ }^{7}$ The iron nails uncovered here possibly suggest the presence of wooden litter or a coffin.

${ }^{8}$ Sparkes, Talcott 1970, 260, no. 349; Moore 1997, 304, no. 1294.

${ }^{9}$ Limberis, Marchenko 2010, 323; 2015, 237.

${ }^{10}$ Moore 1997, 304, no. 1294.

${ }^{11}$ Vdovichenko, Turova 2006, 42, 116-117, Fig. 21, № 134, 135.

12 Robinson 1950, 148-150, 160-162, pl. 105-108.

${ }^{13}$ Rogov, Tunkina 1998, 173-174; Rogov 2011, 120-121.

${ }^{14}$ Reports of the Imperial Archaeological Commission (OAK) in 1912, 54, Fig. 73, above, in the centre; Monakhov et al. 2019, 61, Fig. 46.

${ }^{15}$ Erlikh 2011, 26, 50, Fig. 68, 5. 

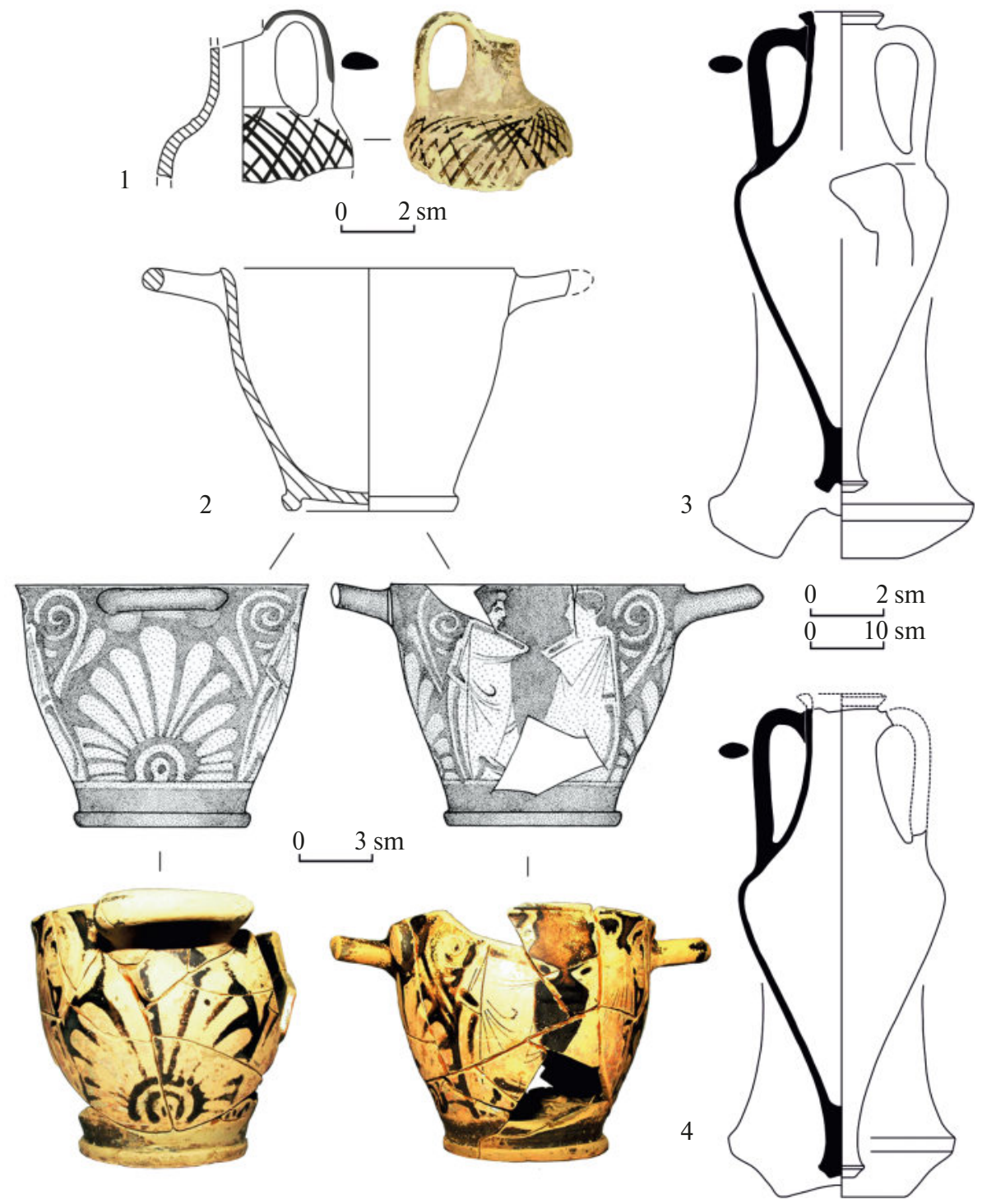

Fig. 1. Imports from burial No. 253 of the Prikubansky necropolis: 1 - net lekythos (KM 11600/1126); 2 - red-figure skyphos (KM 11600/1128); 3, 4- amphorae from Thasos (KM 11600/1120 and KM 11600/1121). Photo and drawings by the authors. Krasnodar, "Krasnodar Historical and Archaeological Museum-Reserve named after E.D. Felitsyn” (GBUK KK “KGIAMZ im. E.D. Felitsyna”)

Lebedi III ${ }^{16}$. They all belong to different issues and are widely dated to the first half of the $4^{\text {th }}$ century B.C. As to the lekythos from burial No. 253, it seems to have belonged to one of the earliest series and, probably, its date can be placed to within the boundaries of the first quarter of the $4^{\text {th }}$ century B.C. At least, a lekythos with exactly the same carefully executed

${ }^{16}$ Limberis, Marchenko 2016a, 67-68. 
'checked' design over the body and with vertical white spots and bands on the throat comes from burial M.04 at the necropolis of Panskoye I, where it was neighbouring an amphora of the 'Murighiol' type of the beginning of the $4^{\text {th }}$ century B.C. ${ }^{17}$

Practically identical Thasian amphorae from burial No. 253 (Pl. 1), one with the rim and handle lost (Fig. 1, 3, 4), belong to the 'early biconical' series (II-B-1). Stamps on the handles or throats are absent inducing us to search for analogues among some reliably dated complexes.

The closest of these parallels include an amphora from the 'Yuzhny' kurgan excavated in 1913 near the stanitsa of Yelizavetinskaya on Kuban, found together with a Heraklean amphora with a stamp of the early fabricant Aristippos ${ }^{18}$, as well as two similar unstamped Thasian amphorae from the Dvugorbaya Mogila kurgan in the Azov Sea region where they were uncovered in association with Heraklean amphorae with stamps of early fabricants Archelas and Eukleiōn ${ }^{19}$. In both cases, the vessels are dated to the very beginning of the $4^{\text {th }}$ century B.C. In addition, there are similar Thasian amphorae with stamps of early magistrates Kuros and Saturos, in the first case from burial No. 254 of the Prikubansky necropolis and, in the second, from room No. 32 in Gorgippia, which, in turn, are well synchronized within the 390s B.C. ${ }^{20}$ In our case, amphorae from burial No. 253 are well correlated with the date of the skyphos from this burial which is datable to within the 390 s - early 380 s B.C.

BURIAL NO. 384

Grave No. 384 was a burial of a male (?) aged 45-50 years old and interred with numerous grave goods: a red-figure skyphos, amphorae from Mende and from an unidentified production centre, grey-ware and handmade vessels of the Maeotian production, ornaments and various small objects.

The red-figure skyphos from this burial has a slightly uncommon profile - its height is somewhat greater retaining the diameter of the rim with the decrease of the diameter of the foot (Pl. 2); the walls near the bottom are distinctly compressed. Forms of blackglazed skyphoi of a similar type are common for the second quarter of the $4^{\text {th }}$ century B.C. ${ }^{21}$ The manner of the painting also somewhat differs: a band of black glaze on the lower body is broader than that of the example from burial No. 253; on both sides, figures of youths in himation are depicted standing at some distance and facing each other. Between them, at the level of the face, a round object, possibly a tympanum, is represented (Fig. 2).

The first amphora (Fig. 3, 1) from this burial is a product of Mende of the 'Portichello' variant (II-B) and has a wedge-shaped rim separated by a slight cut from below, a high neck narrowing beneath the upper attachment of the handles, a smooth transition toward the broad and almost horizontal shoulder, the body of almost conical shape, and

\footnotetext{
${ }^{17}$ Monakhov, Rogov 1990, 127-128, Pl. 4; Rogov, Tunkina 1998, 173, Fig. 7, № 19; Monakhov 2003, 80, Pl. 55, 4.

${ }_{18}$ Monakhov 1999, 177-178, Pl. 65; 2003, 66, tabl. 42, 1-4; Monakhov et al. 2019, 124, Th.9.

${ }^{19}$ Monakhov 1999, 162-163, P1. 55.

${ }^{20}$ Monakhov 1999, 234, P1. 96; 2003, 66-67, P1. 42, 4, 5; Kats 2015, cat. 32.

${ }^{21}$ Sparkes, Talcott 1970, pl. 16, no. 350.
} 
widened profiled foot with a hemispherical hollow. On the handle there is a relief stamp in the form of the letter " $\Delta$ " in a triangular frame. Amphorae of this type are numerously recorded in a series of representative complexes, in particular in the eponimic Porticello Shipwreck, in kurgans No. 2 and at the Yelizavetovskoye necropolis (of 1909), kurgan No. 28 at the cemetery of 'Plavni', in the Chersonesean well of 1992, in room No. 32 in Gorgippia, etc ${ }^{22}$. Through Heraklean and Thasian stamps in these complexes, they are reliably datable to the first two decades of the $4^{\text {th }}$ century B.C. Such Mendean amphorae were retrieved from two other burials of the Prikubansky necropolis (No. 32 and No. 157); moreover in the first of the latter, a Heraklean amphora with a stamp of the early fabricant Dionysios was found together with the amphora from Mende. The amphora from burial No. 157 mentioned above is practically identical to the one under consideration; moreover, it was found accompanying a vessel of the next 'Melitopol' variant dating the amphora from burial No. 384 to within the 370s - early 360s B.C.

The second amphora from burial No. 384 is from an unidentified centre of production (Fig. 3, 2). By the present day it finds no parallels. It has a small beak-shaped rim, a high neck flaring downwards, an ovoid body and a rather low carinated foot with a deep trapezoid hollow. The clay is dark brown on the outside with numerous black inclusions and large quantity of mica and red on the inside. Similar clay is occasionally found in Thasian vessels, however the common morphological features do not allow us to attribute the given example to products of Thasian workshops. On the basis of the date of the Mendean amphora and the skyphos from this burial, this vessel (as also burial No. 384 itself) is datable to the beginning of the second quarter of the $4^{\text {th }}$ century B.C. ${ }^{23}$

BURIAL NO. 186

It was a burial of a man (?) in a wooden coffin. Grave goods: a red-figure skyphos, amphorae from Mende and Knidos, the base of a black-glazed skyphos, a yellow-ware mortar, a bronze cup, handmade and wheelmade grey-ware vessels (including a fish-plate and an askos), a spindle-whorl, a knife with a bone grip, a fragment of a mask-bead, a pebble, different jewelry and a bronze mirror.

The form of the red-figure skyphos is similar to the previously described one. The theme of the painting is the same: depiction of two youths in himation facing each other, between their heads a tympanum is placed (Fig. 4, 1). The manner of depiction is however more careful; the figures touch each other with elbows.

In addition, this burial yielded the foot of a cup-skyphos (Fig. 4, 2) reused as a small cup or a saltcellar. It is a very typical case for the Maeotian world. Only at the Prikubansky necropolis, five foots of vessels of this kind are known ${ }^{24}$. The presence of a decoration combining stamped and carved elements on the inside of the bottom of this foot suggests its date as the beginning of the $4^{\text {th }}$ century B.C..$^{25}$

${ }^{22}$ Monakhov 1999, 165, 176, 183, 188, 223, 233, 243, P1. 57, 64, 68, 72, 93, 96, 99; 2003, 91, Pl. 63, 2; Monakhov et al. 2017, 31, Fig. 7; 2019, 46-47, Fig. 26.

${ }^{23}$ Limberis, Marchenko 2010, 323; Monakhov et al. 2018, 163, 164, Fig. 1, 1.

${ }^{24}$ Limberis, Marchenko 2010, 342, № 21-25.

${ }^{25}$ Sparkes, Talcott 1970, 112, no. 618. 

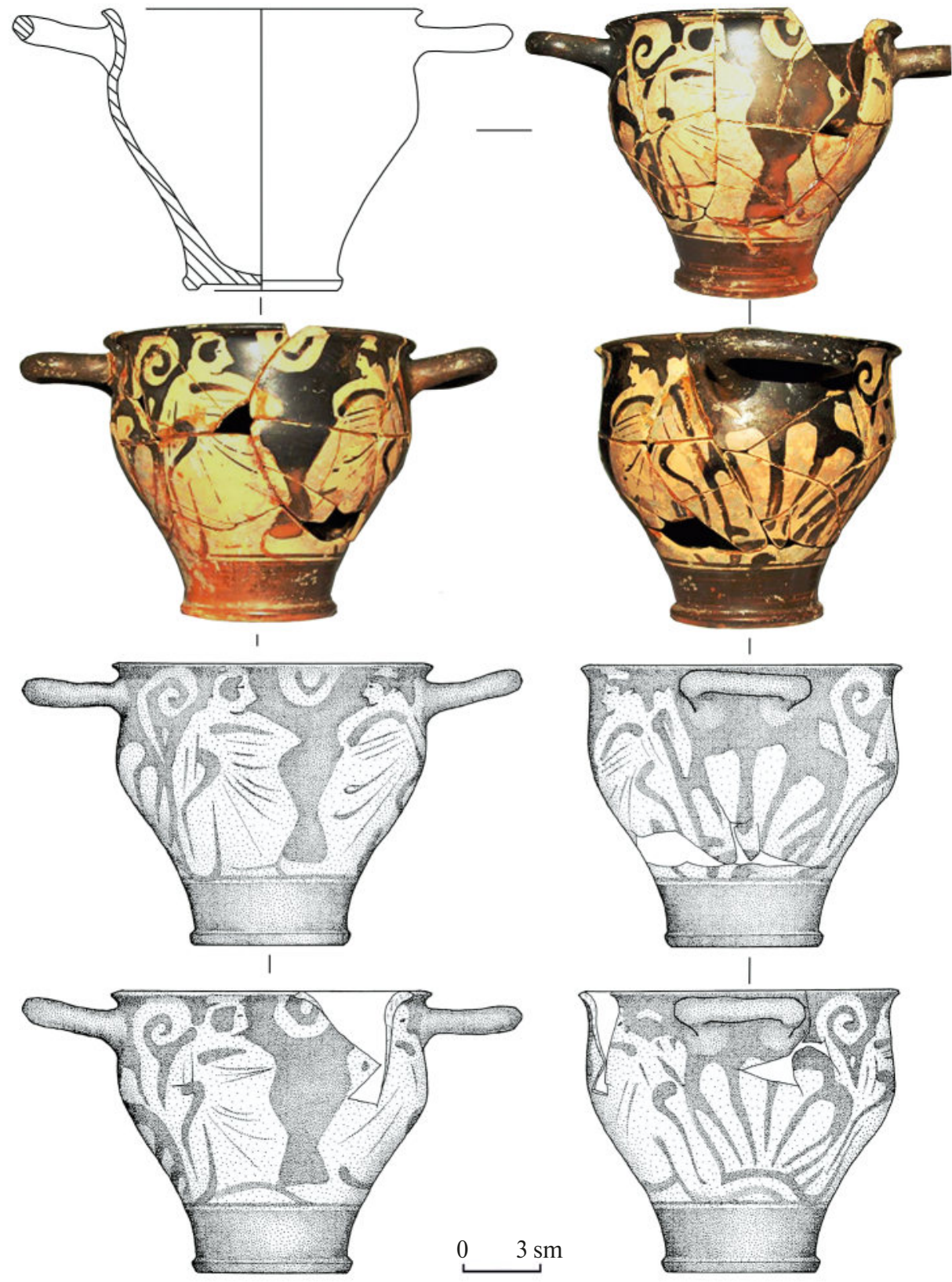

Fig. 2. Red-figure skyphos from burial No. 384 of the Prikubansky necropolis (KM 11600/2186). Photo and drawings by the authors. Krasnodar, "Krasnodar Historical and Archaeological Museum-Reserve named after E.D. Felitsyn” (GBUK KK "KGIAMZ im. E.D. Felitsyna”)

The first amphora from burial No. 186 is of Knidian production; it has a mushroomshaped outturned rim, a relatively low neck slightly tapering downwards (funnel-shaped) 

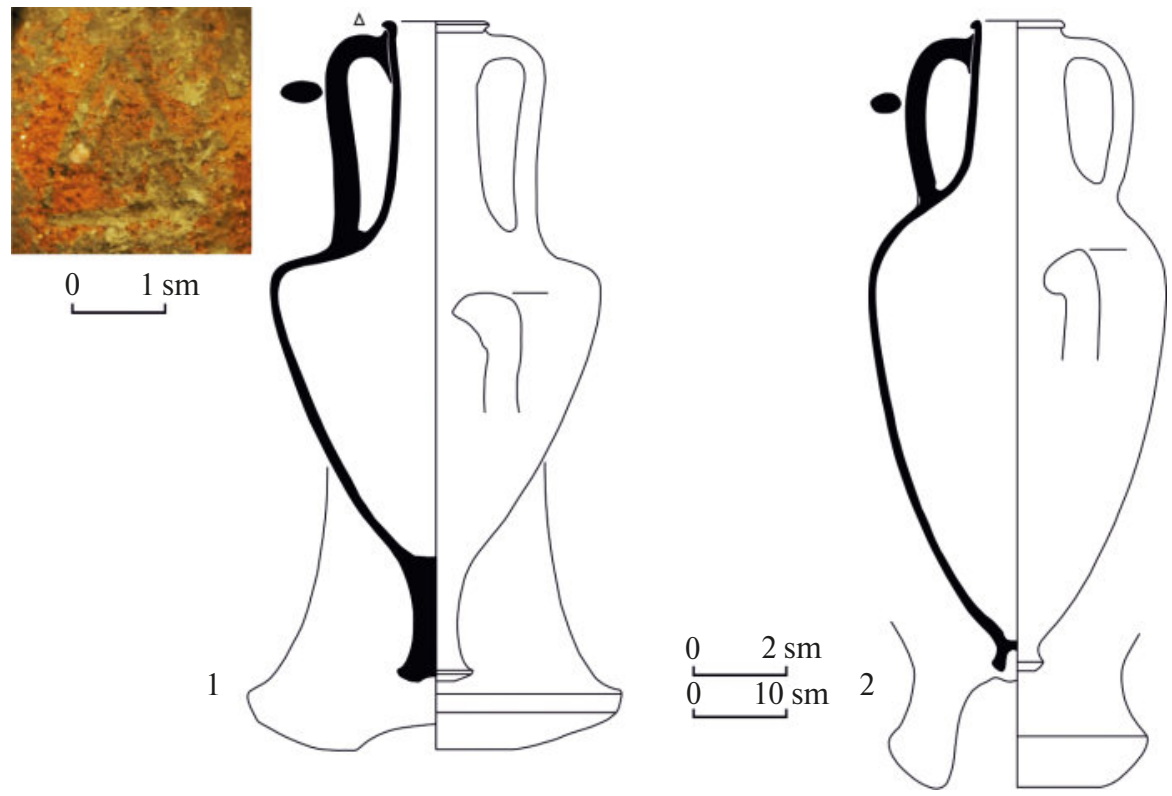

Fig. 3. Amphorae from burial No. 384 of the Prikubansky necropolis: 1 - Mende (KM 11600/2183); 2 - unidentified production centre (KM 11600/2188). Photo and drawings by the authors. Krasnodar, GBUK KK “KGIAMZ im. E.D. Felitsyna”

with a distinct transition to the shoulder. The body is pythoid, the foot is broad carinated with a deep hemispherical hollow. The clay is light brown, soft and dense, containing sparse shell inclusions. Amphorae of this type some time ago were attributed as an independent 'Yelizavetovskoye' variant of Knidian containers (Fig. 4, 3) ${ }^{26}$.

There are numerous analogues to them. Firstly, a similar amphora comes from the central burial of kurgan No. 5 of the 'Five Brothers' group of the Yelizavetovskoye necropolis, whereas at the ritual deposit related with this burial, there were found three Heraklean amphorae with stamps of early fabricants Euridamos and Dionysios 1, as well as still a stray amphora (also from Heraklea) with the stamp of the early fabricant Kromnios ${ }^{27}$. These facts provide us with a chronological link with the late 380 s - early 370 s B.C.

Quite a number of analogous Knidian jars come from several burials of the same Prikubansky necropolis. Thus in burial No. 159, an amphora of this type was encountered together with a biconical Thasian one and a Sinopean amphora (type I-A), which, according to all their analogues, are datable to within the end of the first - beginning of the second quarter of the $4^{\text {th }}$ century B.C. ${ }^{28}$ Moreover, the Thasian amphora bears the

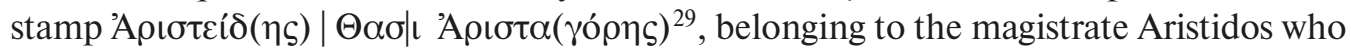

${ }^{26}$ Monakhov 2003, 102, P1. 71, 1-4.

${ }^{27}$ Monakhov 1999, 251-253, Pl. 100.

${ }^{28}$ Limberis, Marchenko 2018, 101, Fig. 3.

${ }^{29}$ Reading by A. B. Kolesnikov. 


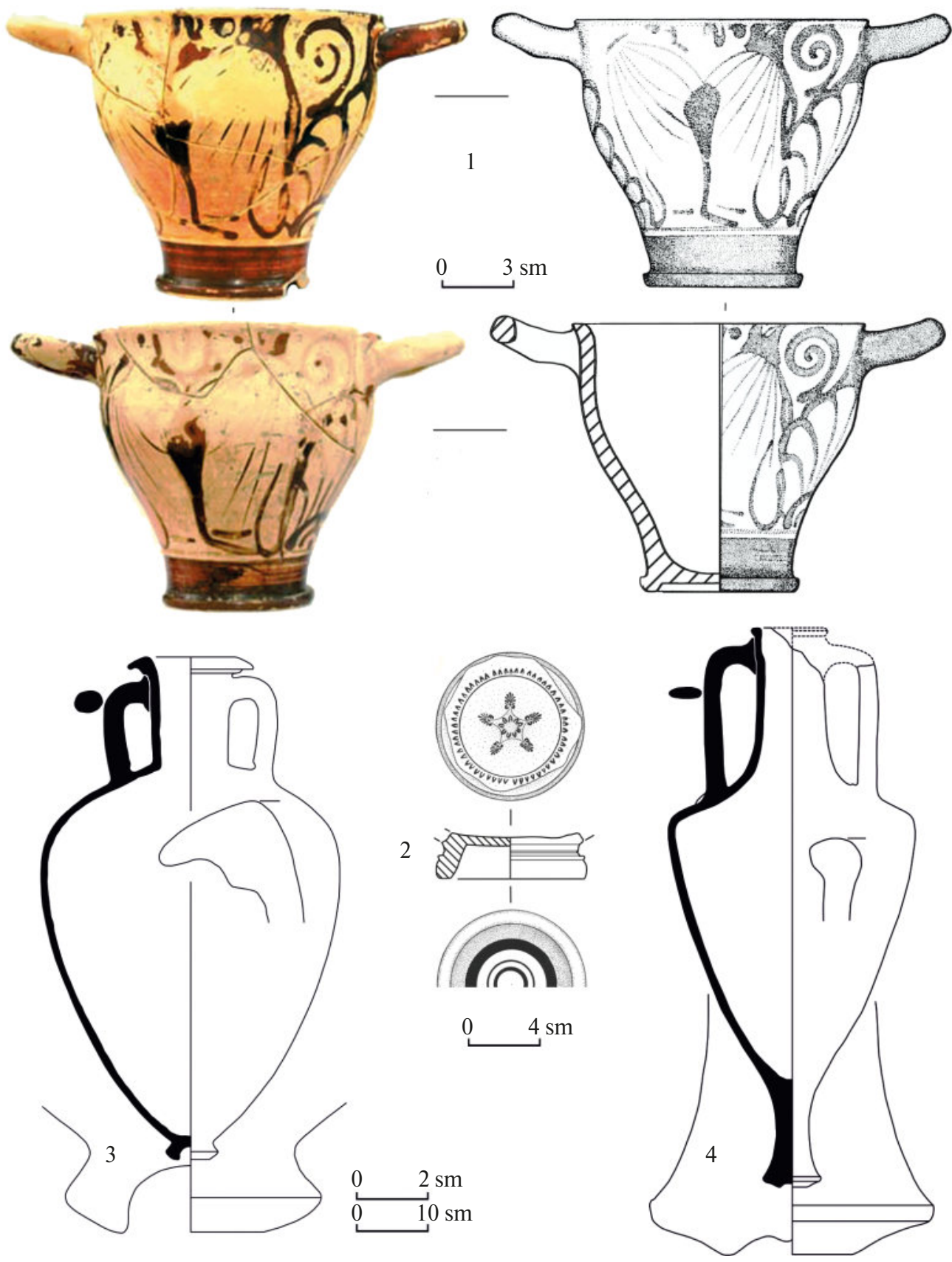

Fig. 4. Imported object from burial No. 186 of the Prikubansky necropolis: 1 - red-figure skyphos (KM 11600/415); 2 - base of black-glazed cup-skyphos (KM 11600/439); 3 - amphora from Knidos (KM 11600/440); 4 - amphora from Mende (KM 11600/438). Photo and drawings by the authors. Krasnodar, GBUK KK “KGIAMZ im. E.D. Felitsyna” 
was active in the 350s B.C. ${ }^{30}$ In burial No. 202 of the Prikubansky necropolis, a Knidian amphora of this type was found together with another large amphora with a mushroom-shaped rim from an unidentified production centre ${ }^{31}$. In burial No. 224 of the same necropolis, the Knidian amphora of the 'Yelizavetovskoye' variant was associated with a Thasian unstamped amphora of the 'developed' biconical series and an Attic black-glazed bolsal ${ }^{32}$. Similar bolsals were distributed particularly in the second half of the $5^{\text {th }}$ century B.C.; in the next century, they began to loose their popularity because of the appearance of kantharoi, but their manufacture continued until the late $4^{\text {th }}$ century B.C. ${ }^{33}$ The closest analogue among the materials of the Athenian Agora is dated to the 380-350 B.C., but its handles are raised upwards as is characteristic of the younger pottery ${ }^{34}$. The bolsal from burial No. 224 is probably dating from the beginning of the second quarter, while the dates of the amphorae from the burial do not exceed the middle of the century.

Finally, burial No. $\mathbf{2 9 4 3}$ of the necropolis of Starokorsunskoye settlement No. 2, yielded together with a Knidian amphora of the same 'Yelizavetovskoye' variant yet another Knidian amphora of the 'Cherednikovy' variant, as well as a black-glazed skyphos and a black-glazed kantharos of the second quarter of this century ${ }^{35}$.

Thus the entire circle of reliably dated parallels indicates the second quarter of the $4^{\text {th }}$ century for the Knidian amphora of the 'Yelizavetovskoye' variant from burial No. 186.

The second amphora from the burial belongs to the Mendean production of the 'Melitopol' variant (Fig. 4, 4). As it was supposed before, this variant is a rather late one but the finds from burial No. 157 of the Prikubansky necropolis of at once two amphorae of the 'Portichello' and 'Melitopol' types suggest that for some time they were manufactured simultaneously. Nevertheless, considering a series of representative complexes with 'Melitopol' amphorae (kurgan No. 1 near the village of Olgino, kurgan No. 4s near v. Petukhovka, kurgan No. 14 near v. Gyunovka, kurgan No. 16 near v. Verkhny Rogachik $^{36}$ ) it seems that the amphora from burial No. 186 should be dated to within the second quarter of the $4^{\text {th }}$ century B.C.

Taking in account the dates of all the categories of imports, the chronology of burial 186 may be placed within the second quarter of the $4^{\text {th }}$ century B.C.

\section{BURIAL NO. 262}

It was the grave of a female (?) 30-40 years old and contained a fairly diverse funerary inventory: a red-figure skyphos, amphorae from Knidos and Mende, a black-glazed saltcellar, Maeotian handmade and grey-ware pottery, diverse jewerly and numerous small objects.

The red-figure skyphos is morphologically identical to the previous one from burial No. 186 (Pl. 2). On its both sides, there are representations of two youths in himation

\footnotetext{
${ }^{30}$ Kats 2007, 415, Supplement II.

${ }^{31}$ Limberis, Marchenko 2018, 101, Fig. 4.

${ }^{32}$ Limberis, Marchenko 2018, 101, Fig. 5.

${ }^{33}$ Sparkes, Talcott, 1970, 108.

${ }^{34}$ Sparkes, Talcott, 1970, 108, no. 558.

${ }^{35}$ Limberis, Marchenko 1997, 83, Fig. 2; Monakhov 2003, 102, Pl. 71, 3; 72, 7.

${ }^{36}$ Monakhov 1999, 220, 276, 379, 381.
} 
facing each other: one with a staff in the right hand, the other - with a strigil in the left (Fig. 5, 1).

The saltcellar with a concave wall belongs to the variant with a recessed underside resembling a pushed-in ring base. This form of saltcellars appeared in Attica in the second half of the $5^{\text {th }}$ century B.C. and became most popular in the second and third quarters of the $4^{\text {th }}$ century B.C. About 315 B.C., their manufacture ceased in Attica ${ }^{37}$. Some researchers supposed that the importation of such saltcellars to the Northern Black Sea region had ended before the mid- $4^{\text {th }}$ century B.C. ${ }^{38}$, however analysis of the mass finds from North-Western Crimea and the Crimean Azov littoral has demonstrated that their main quantity comes from the cultural layers of the third quarter of the $4^{\text {th }}$ century B.C. ${ }^{39}$ Saltcellars of this type were found also in burials nos. 230 and 346 of the second quarter of the $4^{\text {th }}$ century B.C. at the Prikubansky necropolis ${ }^{40}$. In addition, they are known among the ceramic complexes of the Maryanskaya ${ }^{41}$ and Yelizavetinskaya №. № $7 / 1917^{42}$ barrows. An example of the second quarter of the $4^{\text {th }}$ century B.C. is the closest parallel among the materials from the Athenian Agora ${ }^{43}$. These facts entirely correspond to the dating of the skyphos from burial No. 262.

The Knidian amphora from burial No. 262, in terms of its morphological parameters (Pl. 1), belongs to the type with a 'high neck and mushroom-shaped rim', although not to the 'Yelizavetovskoye' but to the 'Gelendzhik' or 'Cherednikov' variant (I-B or I-D) with flattened shoulders, less massive mushroom-shaped rims and a differing, very uncommon, profile of the feet (Fig. 5, 3). The distinguishing of the 'Gelendzhik' variant presently seems not much reliable and moreover only its single examples are now known. Only a single amphora of this variant has been encountered in the complex of burial No. 13 at the necropolis of settlement No. 2 near the Lenin khutor (farmstead) ${ }^{44}$, and moreover in the association with an amphora produced in Erythrai. The latter has not been included in the summary of amphorae from Erythrai but, evidently, it has a number of parallels among the examples of arbitrary type III dated extremely widely to the middle or, perhaps, the third quarter of the $4^{\text {th }}$ century B.C. ${ }^{45}$ The closest analogues come from burial No. 6523 of the necropolis of the Starokorsunskoye settlement No. 2 where two similar vessels were found, as well as a fragmentary amphora from Peparethos and black-glazed ware generally dated to the second quarter of the $4^{\text {th }}$ century B.C. ${ }^{46}$ The abovementioned amphora from burial No. 2943 of the necropolis of the Starokorsunskoye settlement No. 2 is of greater height and slightly lesser diameter.

From the above, it follows that the amphora from burial No. 262 can be dated to the second quarter of the $4^{\text {th }}$ century B.C.

\footnotetext{
${ }^{37}$ Sparkes, Talcott 1970, 137-138, no. 921-938.

38 Rogov, Tunkina 1998, 171.

${ }^{39}$ Egorova 2009, 38, № 359-371; Maslennikov 2012, 180, 182.

${ }^{40}$ Limberis, Marchenko 2010, 335, № 37-39; 2017, 208, № 1-3.

${ }^{41} O A K$ for 1912, 54, Fig. 73, top right; Monakhov et al. 2019, 61, Fig. 46.

42 Galanina 2009, 89, Fig. 4.

43 Sparkes, Talcott 1970, 137-138, no. 936.

${ }^{44}$ Monakhov 2003, 102-103, P1. 71.

${ }^{45}$ Monakhov 2013, 40-41, Pl. V.

${ }^{46}$ Limberis, Marchenko 2016b, 80, Fig. 3.
} 

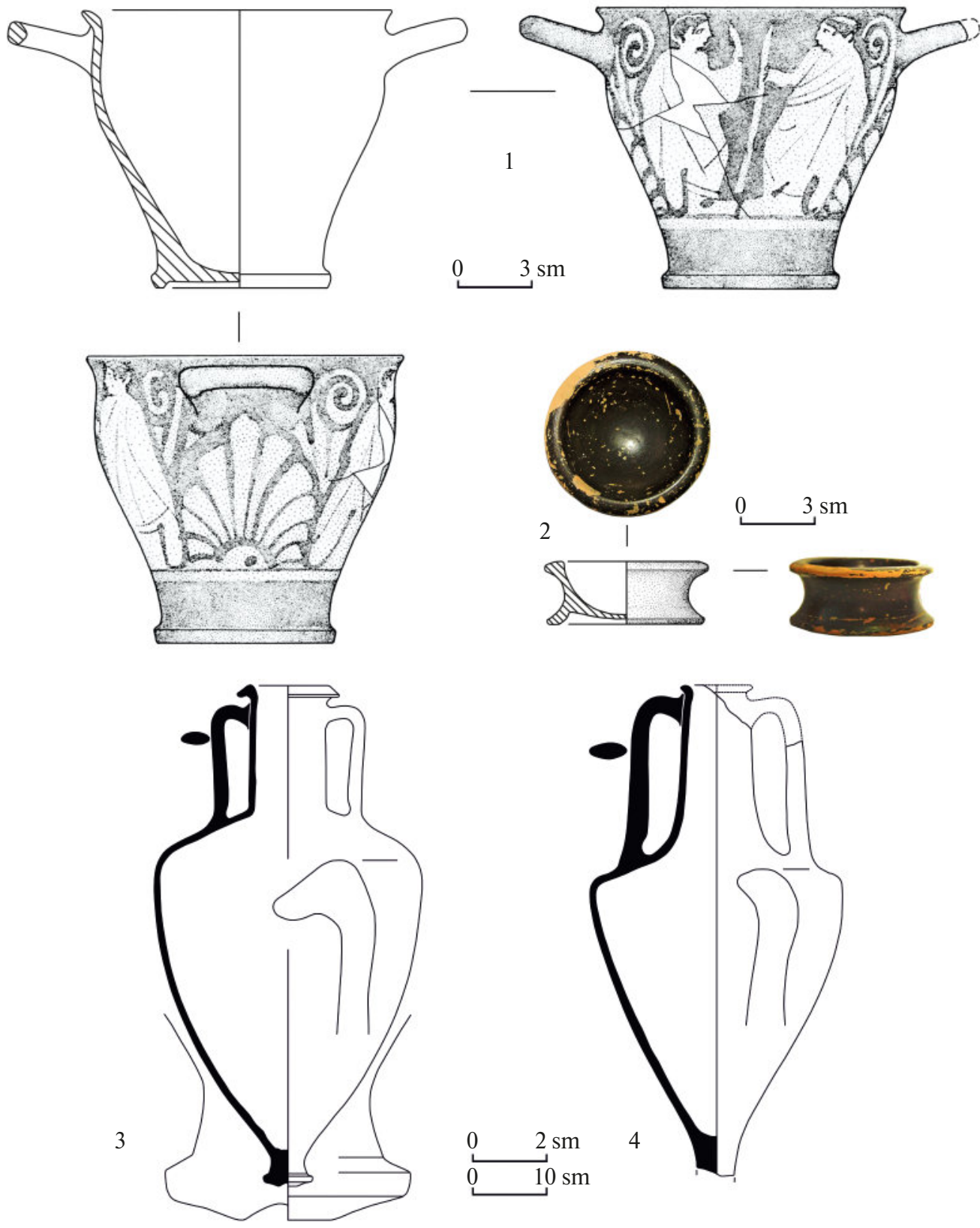

Fig. 5. Imported object from burial No. 262 of the Prikubansky necropolis: 1 - red-figure skyphos (KM 11600/1257); 2 - black-glazed saltcellar (KM 11600/1223); 3 - amphora from Knidos (KM 11600/1217); 4 - amphora from Mende (KM 11600/1219). Photo and drawings by the authors. Krasnodar, GBUK KK "KGIAMZ im. E.D. Felitsyna" 
Amphora from Mende (Fig. 5, 4) is similar to the vessel from burial No. 186 described above and also is datable to within the second quarter of the $4^{\text {th }}$ century B.C.

Generally, the burials with amphorae and red-figure skyphoi in the 'fluent' style are datable to within a fairly limited range of the 380 s-350s B.C. Comparison of the dates of these two categories of grave goods, along with a consideration of known analogues of the little numerous other imports has allowed us to obtain slightly more narrow dates than those defined earlier, to describe in more details the chronology of the skyphoi and to date the complexes in general. In turn, this enables us to define more precisely the time of the manufacture and use of different objects of Maeotian production, mainly pottery.

Table 1

Metric parameters of amphorae from the Prikubansky necropolis ${ }^{47}$

\begin{tabular}{|c|c|c|c|c|c|c|c|c|c|}
\hline \multirow{2}{*}{$\begin{array}{c}\text { Burial } \\
\text { No. }\end{array}$} & \multirow{2}{*}{$\begin{array}{c}\text { Production } \\
\text { centre }\end{array}$} & \multicolumn{6}{|c|}{ Linear dimensions, mm } & \multirow{2}{*}{ Date, B.C. } & \multirow{2}{*}{ Fig. } \\
\hline & & $\mathbf{H}$ & $\mathrm{H}_{0}$ & $\mathrm{H}_{1}$ & $\mathrm{H}_{3}$ & D & $d_{1}$ & & \\
\hline 253 & Thasos & 660 & 572 & 260 & 155 & 290 & 115 & \multirow{2}{*}{$390 \mathrm{~s}$} & 1,4 \\
\hline 253 & Thasos & - & 567 & 281 & 187 & 280 & - & & 1,3 \\
\hline 384 & Mende & 710 & 576 & 290 & 213 & 358 & 116 & 370 s - early 360 s & 3,1 \\
\hline 384 & $\begin{array}{c}\text { Unidentified } \\
\text { centre }\end{array}$ & 700 & 668 & 300 & 160 & 315 & 100 & 370 -e - early 360 s & 3,2 \\
\hline 186 & Knidos & 706 & 675 & 310 & 150 & 420 & 176 & $\begin{array}{l}\text { Second quarter of the } \\
4^{\text {th }} \text { cent. }\end{array}$ & 4,3 \\
\hline 186 & Mende & 786 & 635 & 290 & 202 & 344 & 110 & $\begin{array}{l}\text { Second quarter of the } \\
4^{\text {th }} \text { cent. }\end{array}$ & 4,4 \\
\hline 262 & Knidos & 678 & 630 & 270 & 170 & 366 & 140 & $\begin{array}{l}\text { Second quarter of the } \\
4^{\text {th }} \text { cent. }\end{array}$ & 5,3 \\
\hline 262 & Mende & - & 612 & 280 & 209 & 340 & 96 & $\begin{array}{l}\text { Second quarter of the } \\
4^{\text {th }} \text { cent. }\end{array}$ & 5,4 \\
\hline
\end{tabular}

Table 2

Metric parameters of skyphoi from the Prikubansky necropolis

\begin{tabular}{|c|c|c|c|c|c|c|}
\hline \multirow{2}{*}{$\begin{array}{c}\text { Burial } \\
\text { No. }\end{array}$} & \multirow{2}{*}{$\begin{array}{c}\text { Manufacturing } \\
\text { centre }\end{array}$} & \multicolumn{3}{|c|}{ Linear dimensions, $\mathrm{mm}$} & \multirow[t]{2}{*}{ Date, B.C. } & \multirow[t]{2}{*}{ Fig. } \\
\hline & & $\mathbf{H}$ & d of throat & d of base & & \\
\hline 253 & Attica & 100 & 121 & 73 & $390 \mathrm{~s}-$ early $380 \mathrm{~s}$ & 1,2 \\
\hline 384 & Attica & 109 & 123 & 61 & 370 s - early $360 \mathrm{~s}$ & 2 \\
\hline 186 & Attica & 113 & 122 & 67 & Second quarter of the $4^{\text {th }}$ cent. & 4,1 \\
\hline 262 & Attica & 113 & 126 & 73 & Second quarter of the $4^{\text {th }}$ cent. & 5,1 \\
\hline
\end{tabular}

\section{References}

Brashinskiy, I.B. 1980: Grecheskiy keramicheskiy import na Nizhnem Donu v V-III vv. do n.e. [Greek Ceramic Imports on the Lower Don in $5^{\text {th }}-3^{\text {rd }}$ cent. BC]. Leningrad.

Брашинский, И.Б. Греческий керамический импорт на Нижнем Дону в $V$-III вв. до н.э. Л. Egorova, T.V. 2009: Chernolakovaya keramika IV-II vv. do n.e. s pamyatnikov Severo-Zapadnogo Kryma [Black-Glazed Pottery of the $4^{\text {th }}-2^{\text {nd }}$ cent. BC from the North-Western Crimea Settlements]. Moscow.

${ }^{47} \mathrm{H}$ - height; $\mathrm{H}_{0}-$ depth; $\mathrm{H}_{1}-$ height of the upper body; $\mathrm{H}_{3}-$ height of the neck; $\mathrm{D}-$ diameter of the body; $d_{1}-$ diameter of the rim. 
Егорова, Т.В. Чернолаковая керамика IV-II вв. до н.э. с памятников Северо-Западного Крымa. M.

Erlikh, V.R. 2011: Svyatilishcha nekropolya II Tenginskogo gorodishcha (IVv. do n.e.) [The Sanctuaries of the Necropolis II Tenginsky Settlement (4th cent. BC)]. Moscow.

Эрлих, В.Р. Святилища некрополя II Тенгинского городища (IV в. до н.э.). М.

Galanina, L.K. 2009: [Contacts of Prikuban' Region with the ancient world (based on the materials of the Elizavethian burial mounds)]. In: Epokha rannego zheleza. Sbornik nauchnykh trudov k 60-letiyu S.A. Skorogo [The Early Iron Age. Proceeding by the $60^{\text {th }}$ Anniversary of Sergey Skory, Doctor of Archaeology]. Kiev-Poltava, 86-90.

Галанина, Л.К. Контакты Прикубанья с античным миром (по материалам Елизаветинских курганов). В сб.: Эпоха раннего железа. Сборник научных трудов к 60-летию С.А. Скорого. Киев-Полтава, 86-90.

Ivanov, T. 1963: [Ancient pottery from necropolis of Apollonia]. In: Apoloniya, Razkopkite v nekropole na Apoloniya prez 1947-1949 [Apollonia. Excavations of the Necropolis of Apollonia in 1947-1949]. Sofia, 65-273.

Иванов, Т. Антична керамика от некрополя на Аполония. В сб.: Аполония. Разкопките в некропола на Аполония през 1947-1949. София, 65-273.

Kats, V.I. 2007: Grecheskie keramicheskie kleyma epokhi klassiki i ellinizma (opyt kompleksnogo izucheniya) [Greek Ceramic Stamps of the Classical and Hellenistic Epoch (Complex Research Result)]. Simferopol-Kerch.

Кац, В.И. Греческие керамические клейма эпохи классики и эллинизма (опыт комплексного изучения). (БИ, ХVIII). Симферополь-Керчь.

Kats, V.I. 2015: Keramicheskie kleyma Aziatskogo Bospora. Gorgippiya i ee khora, Semibratnee gorodishche. Katalog [Ceramic Stamps of Asiatic Bosporus. Gorgippia and its Chora, Semibratnee Settlement. Catalogue]. Saratov.

Кац, В.И. Керамические клейма Азиатского Боспора. Горгиппия и ее хора, Семибратнее городище. Каталог. Саратов.

Leskov, A.M., Lapushnian, V.L. (eds.) 1987: Shedevry drevnego iskusstva Kubani. Katalog vystavki [Art Treasures of Ancient Kuban. Catalogue of Exhibition]. Moscow.

Лесков, А.М., Лапушнян, В.Л. (ред.). Шедевры древнего искусства Кубани. Каталог выстав$\kappa u$. M.

Limberis, N.Yu., Marchenko, I.I. 1997: [Burials with the Heraklean amphorae from the excavations of the Necropolis of settlement Starokorsunskoe no. 2]. In: M.Yu. Vakhtina, Yu.A. Vinogradov (eds.), Stratum Plus. Peterburgskiy arkheologicheskiy vestnik [Stratum Plus. Archaeological Bulletin of Saint Petersburg]. Saint Petersburg-Chișinău, 81-93.

Лимберис, Н.Ю., Марченко, И.И. Погребения с гераклейскими амфорами из раскопок могильника Старокорсунского городища № 2. В сб.: М.Ю. Вахтина, Ю.А. Виноградов (ред.), Стратум плюс. Петербургский археологический вестник. Санкт-Петербург-Кишинев, 81-93.

Limberis, N.Yu., Marchenko, I.I. 2010: [Painted and black-glazed pottery from the cemetery of Prikubanskiy (attribution and chronology)]. Drevnosti Bospora [Antiquities of Bosporus] 14, 322-356. Лимберис, Н.Ю., Марченко, И.И. Расписные и чернолаковые сосуды из Прикубанского могильника (атрибуция и хронология). Древности Боспора 14, 322-356.

Limberis, N.Yu., Marchenko, I.I. 2015: [Black-glazed skythos from Meotian settlements of the right bank of the Kuban River]. Drevnosti Bospora [Antiquities of Bosporus] 19, 227-255.

Лимберис, Н.Ю., Марченко, И.И. Чернолаковые скифосы из меотских памятников правобережья Кубани. Древности Боспора 19, 227-255.

Limberis, N.Yu., Marchenko, I.I. 2016a: [Lekythos in Meotian funeral rites on the Kuban right bank]. In: Aziatskiy Bospor i Prikuban'e v dorimskoe vremya [Asian Bosporus and Kuban Region in PreRoman Time]. Moscow, 64-70.

Лимберис, Н.Ю., Марченко, И.И. Лекифы в погребальном обряде меотов Правобережья Кубани. Азиатский Боспор и Прикубанье в доримское время. М., 64-70.

Limberis, N.Yu., Marchenko, I.I. 2016b: [A burial with a glass cup from the cemetery of Stary-Korsun city-site no. 2]. Arkheologicheskie vesti [Archaeological News] 22, 76-85.

Лимберис, Н.Ю., Марченко, И.И. Погребение со стеклянной чашей из могильника Старокорсунского городища № 2. Археологические вести 22, 76-85. 
Limberis, N.Yu., Marchenko, I.I. 2017: [Small black-glazed vessels for food service from Meotian burial grounds at the Right Banks of the Kuban River]. Antichnyi mir i arkheologiya [Ancient World and Archaeology] 18, 206-223.

Лимберис, Н.Ю., Марченко, И.И. Миниатюрные чернолаковые сосуды для сервировки стола из меотских могильников правобережья Кубани. Античный мир и археология 18, 206-223.

Limberis, N.Yu., Marchenko, I.I. 2018: [Chronology of the burials with animal-style horse harness from the Prikubansky burial ground]. Vestnik Volgogradskogo gosudarstvennogo universiteta. Seriya 4, Istoriya. Regionovedenie. Mezhdunarodnye otnosheniya [Science Journal of Volgograd State University. History. Area Studies. International Relations] 23(3), 99-133.

Лимберис, Н.Ю., Марченко, И.И. Хронология погребений с конской упряжью в зверином стиле из Прикубанского могильника. Вестник ВолГУ. Серия 4, История. Регионоведение. Международные отношения 23(3), 99-113.

Maslennikov, A.A. 2012: [Painted pottery from the settlements of the "Royal" chora of the Azov Region]. In: A.A. Maslennikov, Tzarskaya khora Bospora (po materialam raskopok $v$ Krymskom Priazov'e). T. 2. Individual'nye nakhodki i massovyy arkheologicheskiy material [Royal Chora of Bospor (Based on Archaeological Materials from the Crimean Azov Region). Vol. 2. Individual Finds and Mass Archaeological Material]. Moscow.

Масленников, А.А. Расписная керамика с памятников «царской» хоры Приазовья. В кн.: А.А. Масленников, Царская хора Боспора (по материалам раскопок в Крымском Приазовье). Т. 2. Индивидуальные находки и массовый археологический материал. (ДБ, Suppl. III). М.

Monakhov, S.Yu. 1999: Grecheskie amfory v Prichernomor'e: kompleksy keramicheskoy tary VII-II vv. do n.e. [Greek Amphorae in Black Sea Area: Complexes of Ceramic Containers of the $7^{\text {th }}-2^{\text {nd }}$ cent. B.C.]. Saratov. Монахов, С.Ю. Греческие амфоры в Причерноморье: комплексы керамической тары VII-II вв. до н.э. Саратов.

Monakhov, S.Yu. 2003: Grecheskie amfory v Prichernomor'e: tipologiya amfor vedushchikh tsentroveksporterov tovarov v keramicheskoy tare. Katalog-opredelitel' [Greek Amphorae in Black Sea Area: The Typology of Amphorae of the Leading Centers-Exporters of Goods in Ceramic Containers. Catalogue]. Moscow-Saratov.

Монахов, С.Ю. Греческие амфоры в Причерноморье: типология амфор ведущих иентровэкспортеров товаров в керамической таре. Каталог-определитель. Москва-Саратов.

Monakhov, S.Yu. 2013: [Notes on localization of ceramic ware. III. Amphorae of Erythrai (Asia Minor) and their stamps]. Vestnik drevney istorii [Journal of Ancient History] 3, 28-51.

Монахов, С.Ю. Заметки по локализации керамической тары. III. Амфоры и амфорные клейма малоазийских Эрифр. ВДИ 3, 28-51.

Monakhov, S.Yu., Rogov, E.Ya. 1990: [Ceramic complexes of the Necropolis Panskoe I]. Antichnyy mir $i$ arkheologiya [Ancient World and Archaeology] 8, 122-151.

Монахов, С.Ю., Рогов, Е.Я. Керамические комплексы некрополя Панское І. Античный мир и археология 8, 122-151.

Monakhov, S.Yu., Kuznetsova, E.V., Churekova, N.B. 2017: Amfory V-II vv. do n.e. iz sobraniya gosudarstvennogo istoriko-arkheologicheskogo muzeya-zapovednika «Khersones Tavricheskiy». Katalog [Amphorae of the $5^{\text {th }}-2^{\text {nd }}$ cent. BC from the Collection of the State Museum-Preserve "Tauric Chersonese”. Catalogue]. Saratov.

Монахов, С.Ю., Кузнецова, Е.В., Чурекова, Н.Б. Амфоры V-II вв. до н.э. из собрания государственного историко-археологического музея-заповедника «Херсонес Таврический». Каталог. Саратов.

Monakhov, S.Yu., Kuznetsova, E.V., Limberis, N.Yu., Marchenko, I.I. 2018: [Rare forms of amphorae from the Prikubansky necropolis]. In: V.V. Mayko (ed.), Arkheologiya antichnogo i srednevekovogo goroda [Archaeology of the Ancient and Medieval City]. Sevastopol-Kaliningrad, 163-170.

Монахов, С.Ю., Кузнецова, Е.В., Лимберис, Н.Ю., Марченко, И.И. Редкие формы амфор из Прикубанского некрополя. В сб.: В.В. Майко (ред.), Археология античного и средневекового города. Севастополь-Калининград, 163-170.

Monakhov, S.Yu., Kuznetsova, E.V., Chistov, D.E., Churekova, N.B. 2019: Antichnaya amfornaya kollektsiya Gosudarstvennogo Ermitazha VI-II vv. do n.e. Katalog [The Ancient Amphorae Collection of The State Hermitage Museum $6^{\text {th }}-2^{\text {nd }}$ cent. BC. Catalogue]. Saratov.

Монахов, С.Ю., Кузнецова, Е.В., Чистов, Д.Е., Чурекова, Н.Б. Античная амфорная коллекиия Государственного Эрмитажа VI-II вв. до н.э. Каталог. Саратов. 
Moore, M.B. 1997: Attic Red-Figured and White-Ground Pottery. (The Athenian Agora, 30). Princeton (NJ). Picazo, M. 1977: Las Cerámicas Áticas de Ullastret. Barcelona.

Rogov, E.Ya., Tunkina, I.V. 1998: [Painted and black-glazed pottery from the necropolis Panskoe I]. Arkheologicheskie vesti [Archaeological News] 5, 159-175.

Рогов, Е.Я., Тункина, И.В. Расписная и чернолаковая керамика из некрополя Панское I. Археологические вести 5, 159-175.

Rogov, E.Ya. 2011: Nekropol' Panskoe 1 v Severo-Zapadnom Krymu [Necropolis Panskoye 1 in the North-Western Crimea]. Simferopol.

Рогов, Е.Я. Некрополь Панское 1 в Северо-Западном Крыму. (МАИЭТ, Suppl. 10). Симферополь.

Robinson, D.M. 1950: Excavaition at Olinthus. Pt. XIII. Vases Found in 1934 and 1938. (The Johns Hopkins University Studies in Archaeology, 38). Baltimore.

Sparkes, B.A., Talcott, L. 1970: Black and Plain Pottery of $6^{\text {th }}-5^{\text {th }}$ and $4^{\text {th }}$ Centuries BC. Pt. I. Text. Pt. II. Indexes and Illustrations. (The Athenian Agora, XII). Princeton (NJ).

Stoyanov, R.V., Erim-Ozdogan, A. 2014: [Collection of black-figured and red-figured pottery from the excavations of the Menekse Çatağı settlement in Propontis]. Zapiski Instituta istorii material'noy kul'tury [Transactions of the Institute for the History of Material Culture] 10, 166-179.

Стоянов, Р.В., Ерим-Оздоган, А. Коллекция черно- и краснофигурной керамики из раскопок поселения Менекше Чатай в Пропонтиде. Записки ИИМК РАН 10, 166-179.

Trias de Arribas, G. 1967-1968: Ceramicas griegas de la Peninsula Iberica. Vol. I-II. (Publicaciones de Arqueologia Hispanica, II). Valencia.

Vdovichenko, I.I., Turova, N.P. 2006: Antichnye raspisnye vazy iz sobraniya Yaltinskogo istorikoliteraturnogo muzeya [Antique Painted Vases of the Yalta Museum of History and Literature Collection]. Simferopol-Kerch.

Вдовиченко, И.И., Турова, Н.П. Античные расписные вазы из собрания Ялтинского историко-литературного музея. (БИ, ХIV). Симферополь-Керчь.

Vdovichenko, I.I., Ryzhov, S.G., Zhestkova, G.I. 2019: Antichnaya raspisnaya keramika Khersonesa Tavricheskogo. Iz raskopok S.G. Ryzhova v 1976-2011 godakh [Ancient Painted Pottery of Tauric Chersonesos. From the Excavations of S.G. Ryzhov in 1976-2011]. Sevastopol.

Вдовиченко, И.И., Рыжов, С.Г., Жесткова, Г.И. Античная расписная керамика Херсонеса Таврического. Из раскопок С.Г. Рыжкова в 1976-2011 годах. Севастополь. 